Paulina Matracka

Aleksandra Wicka

Szkoła Glówna Gospodarstwa Wiejskiego w Warszawie

\title{
Znaczenie sposobu ustalania sumy ubezpieczenia w procesie zarządzania ryzykiem poprzez ubezpieczenie (studium przypadku)
}

\section{THE IMPORTANCE OF THE METHOD OF DETERMINING THE SUM INSURED IN THE PROCESS OF RISK MANAGEMENT THROUGH INSURANCE (case study)}

\begin{abstract}
Celem artykutu jest przedstawienie konsekwencji ustalania, przy zawieraniu umowy ubezpieczenia, sumy ubezpieczenia w oparciu o niewłaściwa wartość przedmiotu ubezpieczenia. Wnioski w nim zawarte oparte zostały na analizie polis dotyczqcych ochrony obiektu sakralnego $i$ jednostki samorzadu terytorialnego. W opracowaniu przedstawiono problem niedoubezpieczenia opierajac się na literaturze przedmiot $i$ dokumentacji szkodowej firm ubezpieczeniowych. Wyniki analizy potwierdzaja teze, że niedoubezpieczenie jest przyczyna nieprawidtowego $i$ niesatysfakcjonujacego ubezpieczonego zakończenia procesu zarzqdzania ryzykiem poprzez ubezpieczenie.
\end{abstract}

Słowa kluczowe: ubezpieczenia, suma ubezpieczenia, wartość przedmiotu ubezpieczenia, umowa ubezpieczeniowa, zarządzanie ryzykiem, odszkodowanie

\section{Wstęp}

Ubezpieczenie jako metoda zarządzania ryzykiem ma za zadanie zamienić dotkliwą stratę finansową, która może powstać $\mathrm{w}$ związku $\mathrm{z}$ wystapieniem negatywnego zdarzenia losowego, na niewielki, przewidywalny koszt, czyli składkę ubezpieczeniową. Zawarcie umowy ubezpieczenia daje więc gwarancję wypłaty odszkodowania w sytuacji wystapienia wypadku ubezpieczeniowego ${ }^{1}$. Wybór tej formy manipulacji ryzykiem ${ }^{2}$ zapewnia poczucie bezpieczeństwa zarówno klientom indywidualnym jak i podmiotom gospodarczym, które nie muszą odkładać środków na wypadek zaistnienia zdarzenia losowego. Nadrzędnym celem tych działań jest, szczególnie w przypadku firm, zapewnienie przedsiębiorstwu jak najlepszych warunków do wzrostu i rozwoju. ${ }^{3}$

Zdecydowanie lepiej jest ponieść mniejszy koszt za zakup ubezpieczenia niż ogromne wydatki na odbudowę zniszczonego mienia. Często do wypadku w ogóle nie

\footnotetext{
${ }^{1}$ A. Wicka, Finanse ubezpieczeń gospodarczych [w:] Finanse-teoria i praktyka. Podstawka M. (red.) PWN, Warszawa 2017

${ }^{2}$ G. Strupczewski, Ryzyko i zarządzanie ryzykiem [w:] Współczesne ubezpieczenia gospodarcze, pod red. W. Sułkowskiej, Wydawnictwo Uniwersytetu Ekonomicznego w Krakowie, Kraków 2013

${ }^{3}$ A.C. Williams J r., M.L. Smith, P.C. Young, Zarządzanie ryzykiem a ubezpieczenia, PWN, Warszawa 2002
} 
dochodzi i odszkodowanie nie jest wypłacane. Co jednak w sytuacji gdy cykl produkcyjny produktu ubezpieczeniowego zrealizuje się do ostatniej fazy ${ }^{4}$ i zajdzie zdarzenie losowe? Wówczas warto mieć zabezpieczenie finansowe $\mathrm{w}$ postaci ubezpieczenia, pod warunkiem że suma ubezpieczenia, która stanowi górną granicę odpowiedzialności ubezpieczyciela jest właściwie określona. Ustalenie odpowiedniej wartości sumy ubezpieczenia jest więc jednym z najistotniejszych elementów na które trzeba zwrócić uwagę dokonując zakupu ubezpieczenia.

Towarzystwa ubezpieczeniowe przeprowadzają bardzo szczegółową analizę statystyczną zawartych umów ubezpieczeniowych. Skupiają się one jednak głównie na analizie i ocenie przyjmowanych do ubezpieczenia ryzyk. Decyzję o wysokości sumy ubezpieczenia podejmuje klient i to on musi liczyć się z konsekwencjami niewłaściwego jej określenia. Częściej klienci zaniżają niż zawyżają wartość ubezpieczanego mienia. Prowadzi to do sytuacji niedoubezpieczenia, a co za tym idzie do zaniżenia wypłacanego odszkodowania. Z punktu widzenia zakładu ubezpieczeń nie jest to aż tak istotne, gdyż nie ponosi on dodatkowego ryzyka związanego $\mathrm{z}$ wyborem sposobu jej ustalania. Jedyne konsekwencje, z którymi może się mierzyć dotyczą wizerunku marketingowego, skarg do Rzecznika Finansowego, czy straty klienta. Duża część skarg spływających do Rzecznika Finansowego dotyczy właśnie wysokości przyznanego odszkodowania lub świadczenia, a dokładniej ustalenia przez zakład ubezpieczeń nieadekwatnej do rozmiaru szkody wysokości odszkodowania. Znaczna liczba sporów dotyczy również sposobu i nieprawidłowości $\mathrm{w}$ działaniach zakładów ubezpieczeń podejmowanych $\mathrm{w}$ procesie likwidacji szkody oraz odmowy wypłaty odszkodowania. To właśnie poziom finansowego pokrycia strat, nieterminowość procesu likwidacji szkód, wydłużony termin realizacji odszkodowania, liczne wyłączenia oraz poziom ceny bardzo wypływają na niezadowolenie klientów z usług ubezpieczeniowych.

\section{Cel i metody badawcze}

Celem artykułu jest przedstawienie konsekwencji jakie niesie ze sobą dla klienta ustalenie sumy ubezpieczenia na podstawie zaniżonej wartości przedmiotu ubezpieczenia. Przedmiotem analiz były zawarte umowy ubezpieczenia, w których wystąpił problem niedoubezpieczenia oraz skutki tych sytuacji, z punktu widzenia wypłaty odszkodowania.

Materiał źródłowy stanowiła literatura przedmiotu składająca się artykułów branżowych i analiza zapisów Kodeksu Cywilnego, Ustawy o ubezpieczeniach obowiązkowych, Ubezpieczeniowym Funduszu Gwarancyjnym i Polskim Biurze Ubezpieczycieli Komunikacyjnych oraz Ustawy o działalności ubezpieczeniowej.

Metoda dokumentacyjna polegała na analizie zaistniałych szkód w Towarzystwie Ubezpieczeń Wzajemnych „TUW” oraz Uniqa Insurance Group S.A w latach 20142017. Badaniu poddane zostały zostały materiały wewnętrzne towarzystw ubezpieczeniowych tj. umowy ubezpieczeniowe i teczki szkodowe, na podstawie których opracowano przedstawione $\mathrm{w}$ artykule studium przypadku.

\footnotetext{
${ }^{4}$ A. Szromnik, Rynek ubezpieczeniowy. Społeczne problemy kształtowania i funkcjonowania, Akademia Ekonomiczna w Krakowie, Kraków 2001
} 


\section{Suma ubezpieczenia a wartość ubezpieczenia}

Suma ubezpieczenia określa maksymalną wartość odpowiedzialności zakładu ubezpieczeń. $^{5} \mathrm{~W}$ ubezpieczeniu odpowiedzialności cywilnej nazywana jest sumą gwarancyjną. W przypadku ich wyczerpania ustaje odpowiedzialność ubezpieczyciela. Ubezpieczyciel nie ma obowiązku wypłacać świadczenia przekraczającego wartość przewidzianą w umowie ubezpieczenia. Dla zakresu ochrony ubezpieczeniowej, istotne znaczenie ma wysokość sumy ubezpieczenia, sposób jej ustalania, ewentualne limity i sublimity, odnoszące się do zdarzeń, postaci szkody lub klauzul.

Sposób ustalania sumy ubezpieczenia, w zależności od rodzaju ubezpieczenia, jest różny. W ubezpieczeniach osobowych, w których przedmiotem ubezpieczenia jest życie, zdrowie, zdolność do pracy, trudno jest ocenić wartość sumy ubezpieczenia. W związku z tym ma ona charakter umowny. Jedyny wyjątek stanowią ubezpieczenia kosztów leczenia, gdyż tam możliwa jest wycena zabiegów medycznych, wchodzących w skład pokrywanych przez ubezpieczyciela świadczeń. W ustalaniu wysokości sumy ubezpieczenia, można posłużyć się wielkością zarobków ubezpieczonego, pełnioną przez niego rolą w gospodarstwie domowym oraz poziomem zadłużenia gospodarstwa domowego. Można ją również ustalić na poziomie odpowiedniej krotności zarobków ubezpieczonego lub rat kredytu, czy wartości zadłużenia gospodarstwa domowego. W przypadku zdarzenia ubezpieczeniowego, suma ubezpieczenia może być w całości wypłacona poszkodowanemu (dzieje się tak w przypadku śmierci ubezpieczonego) albo stanowi część sumy ubezpieczenia, odpowiednio pomnożonej przez procent uszczerbku.

W przypadku ubezpieczeń odpowiedzialności cywilnej, suma gwarancyjna jest najwyższą wartością świadczenia za konsekwencje jednego zdarzenia ubezpieczonego lub sumą wszystkich świadczeń na zdarzenia ubezpieczeniowe w czasie trwania okresu ubezpieczenia. Różne sumy ubezpieczenia wyznaczone dla różnych ryzyk, zawarte są w jednej umowie ubezpieczenia. Wyznaczone są one nie tylko przez umowę ubezpieczenia ale również przez ustawę o ubezpieczeniach obowiązkowych ${ }^{6}$. Specyfiką sumy gwarancyjnej jest to, że powinna zabezpieczać nie tylko ubezpieczonego, ale również potencjalnie poszkodowanych działaniem lub zaniechaniem działania przez ubezpieczonego.

W ubezpieczeniach majątkowych suma ubezpieczenia powinna odpowiadać wartości przedmiotu ubezpieczenia. ${ }^{7} \mathrm{~W}$ zależności od składnika majątku, może być ustalana opierając się na wartości: odtworzeniowej ${ }^{8}$, rzeczywistej, upłynnienia, księgowej brutto, księgowej netto lub rynkowej (rys.1).

\footnotetext{
${ }^{5}$ Ustawa z dnia 23 kwietnia 1964 - Kodeks cywilny (t.j. Dz. U. z 2014 r., poz. 121) art. 824 ust. 1

6 Ustawa z dnia 22 maja 2003 r. o ubezpieczeniach obowiązkowych, Ubezpieczeniowym Funduszu Gwarancyjnym i Polskim Biurze Ubezpieczycieli Komunikacyjnych (t.j. Dz.U.2018.0.473)

${ }^{7}$ W. Ronka-Chmielowiec, Ubezpieczenia, CH BECK, Warszawa 2016

${ }^{8}$ R. Stempel. Ubezpieczenia inżynieryjno-techniczne, wyd. UWM Olsztyn, Olsztyn 2013
} 


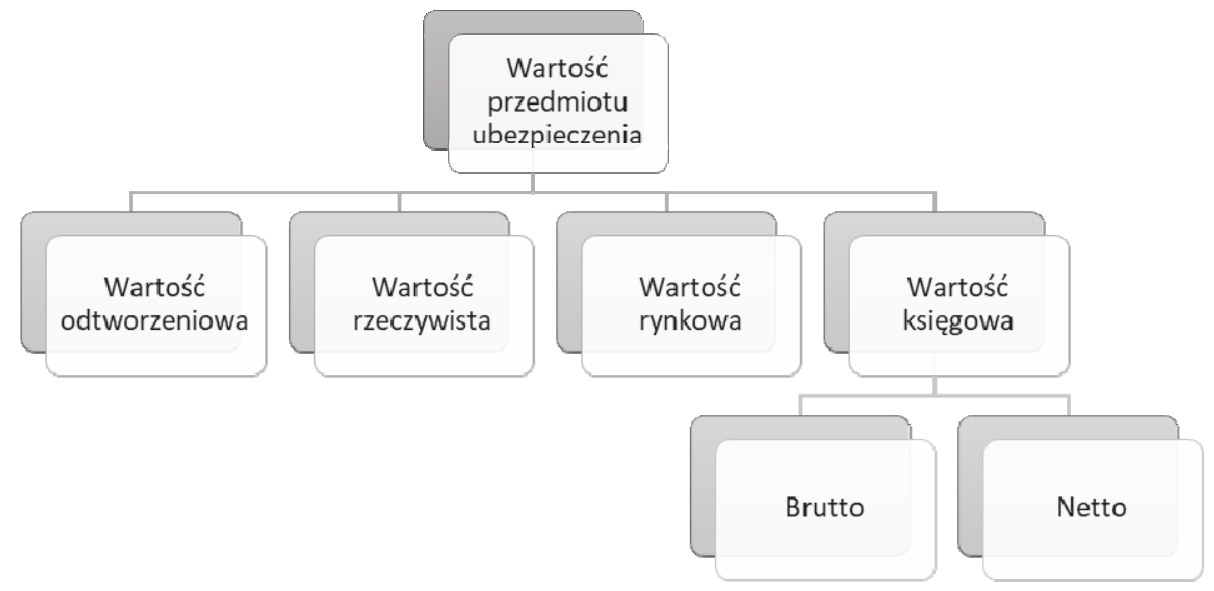

Rysunek 1. Rodzaje wartości przedmiotu ubezpieczenia, którym może odpowiadać suma ubezpieczenia

Źródło: Opracowanie własne

Wartość odtworzeniowa odpowiada kosztom poniesionym w celu przywrócenia przedmiotu ubezpieczenia do stanu sprzed szkody. Zalicza się do niej koszty odbudowy, remontu lub zakupu mienia o tych samych parametrach technicznych, co mienie zniszczone w wyniku zajścia zdarzenia losowego. Powiększona jest dodatkowo o koszty transportu i montażu. Oparcie sumy ubezpieczenia o wartość odtworzeniową zapewnia, w przypadku szkody całkowitej, odtworzenie ubezpieczonego mienia do stanu nowego. W razie szkody częściowej, zapewnia przywrócenie mienia do dalszego funkcjonowania, bez żadnych negatywnych konsekwencji. Stosowana jest do wyceny majątku o małym stopniu zużycia. Większość ubezpieczycieli zakłada, że mienie można ubezpieczyć według wartości odtworzeniowej, jeśli stopień zużycia technicznego nie przekracza od $40 \%$ do $60 \%$.

Wartość rzeczywista jest równa wartości odtworzeniowej pomniejszonej o stopień zużycia technicznego w dniu szkody. Zużycie techniczne nieruchomości wynika z jego wieku, sposobu użytkowania, trwałości materiałów i jakości budownictwa. Stosowana jest do wyceny majątku o znacznym stopniu zużycia.

Wartość rynkowa ustalana jest za pomocą przeciętnych cen rynkowych możliwych do uzyskania za dane mienie. Stosowana jest do wyceny elementów majątku o dużym stopniu zużycia, który nie pozwala na ich dalsze użytkowanie zgodnie $\mathrm{z}$ przeznaczeniem.

Wartość księgowa brutto odpowiada początkowej wartości księgowej mienia, uwzględniając kolejne przeszacowania wartości, według obowiązujących przepisów. Zwyczajowo jest niższa od wartości odtworzeniowej. Wartość księgowa netto to wartość początkowa budynków, budowli czy innych środków trwałych po uwzględnieniu tzw. odpisów amortyzacyjnych. Nie jest to jednak metoda korzystna z punktu widzenia ubezpieczającego. Dla większości składników majątku, wartość ta będzie znacznie 
zaniżona $\mathrm{w}$ stosunku do kwot potrzebnych na naprawę lub odtworzenie zniszczonej maszyny lub jej części. Zgodnie z zasadami, przy ubezpieczeniu na wartość księgową brutto, odszkodowanie za szkodę częściową nie może przekroczyć tej części wartości księgowej początkowej mienia dotkniętego szkoda, jaka odpowiada procentowemu stopniowi jego uszkodzenia. ${ }^{9}$

Wartość księgowa netto ustalana jest poprzez pomniejszenie wartości księgowej brutto o odpisy amortyzacji. Ubezpieczenie na jej podstawie jest bezcelowe, gdyż nie daje żadnej ochrony ubezpieczeniowej. Może zaistnieć sytuacja, że zakład nie wypłaci odszkodowania za szkodę, ponieważ zniszczony sprzęt w całości został zamortyzowany.

Problem wyznaczenia wartości czy sum ubezpieczenia jest najpoważniejszym problemem przed jakim staje ubezpieczający. Nieprawidłowe określenie wartości wpływa na wysokość składki ubezpieczeniowej oraz ostateczną wartość odszkodowania lub świadczenia. Spowodowane jest to schematem ustalania wysokości odszkodowania, w którym bierze się pod uwagę relację miedzy wartością mienia a sumą ubezpieczenia.

W przypadku gdy, wartość przedmiotu ubezpieczenia równa jest sumie ubezpieczenia, świadczy to o pełnym ubezpieczeniu.

Jeśli wartość przedmiotu ubezpieczenia jest mniejsza od sumy ubezpieczenia, ma miejsce zjawisko nadubezpieczenia. Nawet jeśli ubezpieczający płaci wyższą składkę ubezpieczeniową świadczenie wypłacane jest do wysokości wartości przedmiotu ubezpieczenia. Ustalanie wyższej sumy ubezpieczenia, w takim razie jest bezcelowe, gdyż nie przynosi ubezpieczonemu żadnych korzyści w postaci podwyższonego odszkodowania.

Jeśli wartość przedmiotu ubezpieczenia jest większa od sumy ubezpieczenia, występuje zjawisko niedoubezpieczenia. Wówczas odszkodowanie wypłacane jest do wysokości szkody pomniejszonej o wskaźnik niedoubezpieczenia. Ubezpieczający zazwyczaj zaniża wartość przedmiotu ubezpieczenia, po to aby płacić niższą składkę ubezpieczeniową. Musi się on jednak liczyć z konsekwencjami pozornej oszczędności.

W przypadku szkody całkowitej, zakład ubezpieczeń nie ponosi odpowiedzialności za część szkody przewyższającą wartość ubezpieczonego mienia. Ubezpieczającemu zostanie wypłacone odszkodowanie w wysokości sumy ubezpieczenia, uwzględniając zasadę proporcji (rys.2), jeśli ma ona zastosowanie.

\footnotetext{
${ }^{9}$ M. Kaczmarek, Ubezpieczenia majatkowe dla podmiotów gospodarczych [w]: E. Wierzbicka, Ubezpieczenia non-life, CeDeWu Sp. z o.o, Warszawa 2010
} 


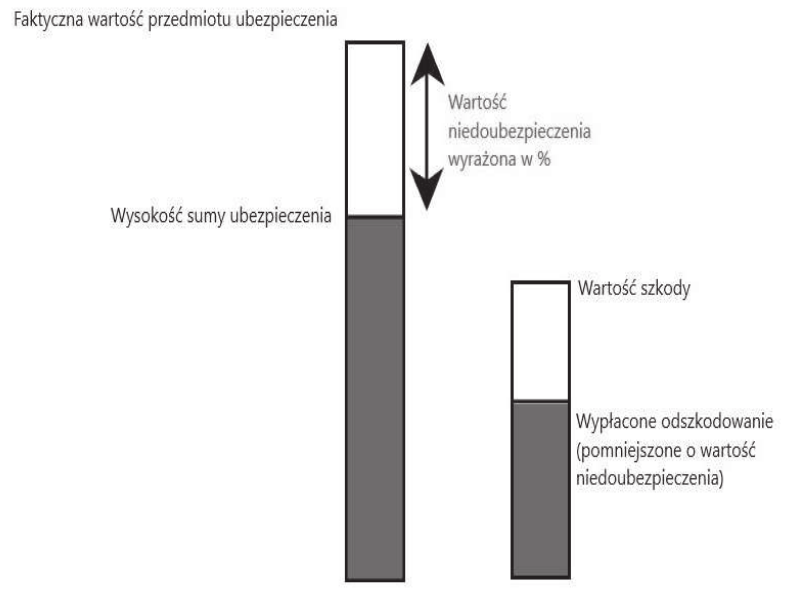

Rysunek 2. Zasada proporcji

Źródło: Opracowanie własne

W przypadku, gdy brak w umowie zapisu o odpowiedzialności proporcjonalnej, ubezpieczenie wypłacane jest zgodnie z przyjętym systemem odpowiedzialności tj. w wysokości wartości szkody. Taki system to odpowiedzialność za pierwsze ryzyko.

Jeśli wystąiła szkoda częściowa, zakład ubezpieczeń wypłaci odszkodowanie według systemu odpowiedzialności proporcjonalnej lub zgodnie z przyjętym systemem odpowiedzialności. Zasada proporcji polega na wypłacie odszkodowania w wysokości, która pozostaje w takiej relacji do wielkości szkody, w jakiej suma ubezpieczenia do wartości ubezpieczeniowej. ${ }^{10}$ Oznacza to, że nawet jeśli wysokość szkody nie przekracza sumy ubezpieczenia, wypłacone odszkodowanie nie wystarczy na pokrycie szkody (Tab.1).

Tabela 1. Wysokość odszkodowania przy niedoubezpieczeniu w różnych systemach odpowiedzialności

\begin{tabular}{|l|l|l|l|l|}
\hline $\begin{array}{l}\text { Suma } \\
\text { ubezpieczenia }\end{array}$ & Wartość mienia & $\begin{array}{l}\text { Wysokość } \\
\text { szkody }\end{array}$ & $\begin{array}{l}\text { Odszkodowanie } \\
\text { odpowiedzialność } \\
\text { pierwsze ryzyko }\end{array}$ & $\begin{array}{l}\text { Odszkodowanie - } \\
\text { nadpowiedzialność } \\
\text { proporcjonalna }\end{array}$ \\
\hline 10000 & 15000 & 8000 & 8000 & 5360 \\
\hline 10000 & 15000 & 12000 & 10000 & 8040 \\
\hline
\end{tabular}

Źródło: Opracowanie na podstawie Hadyniak B., Monkiewicz J., Ubezpieczenia w zarządzaniu ryzykiem przedsiębiorstwa tom 1, Warszawa 2010

Sumy ubezpieczenia mogą być modyfikowane przez klauzule sumy przezornej lub klauzule Leeway. Łagodzą one lub wyłączają skutki niedoubezpieczenia.

${ }^{10}$ M. Orlicki, Umowa ubezpieczenia, CH Beck, Warszawa 2002 
W klauzuli sumy przezornej, wskazana jest konkretna kwota o którą wartość ubezpieczeniowa może być wyższa od podanej przez ubezpieczającego wartości.

W klauzuli Leeway, różnica między wartością ubezpieczeniową mienia, a wartością podaną przez ubezpieczającego, zawarta jest ramach procentowych. Oznacza to, że jeśli niedoubezpieczenie nie przekroczy 20-30\% sumy ubezpieczenia, zasada proporcjonalności nie będzie stosowana.

\section{Niedoubezpieczenie w umowach mienia instytucji sakralnych i publicznych - studium przypadku}

Z sytuacją niedoubezpieczenia mienia można się spotkać dość często w przypadku umów ubezpieczeniowych instytucji publicznych i sakralnych. W niniejszym opracowaniu przytoczono przykłady dwóch szkód precedensowych.

Pierwsza z nich to szkoda pożarowa z 1 lipca 2017 r. Katedry Wniebowzięcia Najświętszej Marii Panny w Gorzowie Wielkopolskim. Katedra ubezpieczona była w Towarzystwie Ubezpieczeń Wzajemnych „TUW”. Analizując tę szkodę, należy najpierw przybliżyć zasady funkcjonowania towarzystw ubezpieczeń wzajemnych, które są odmienne od zasad funkcjonowania towarzystw ubezpieczeniowych w formie spółek akcyjnych. Opierają one swoją działalność na wzajemności ${ }^{11}$, a w przeciwieństwie do towarzystw ubezpieczeniowych działających w formie spółek akcyjnych, nie są nastawione na zysk gdyż są instytucjami non-profit. Ich głównym celem jest zabezpieczenie potrzeb osób w nich ubezpieczonych oraz zapewnienie im pełnej i stosunkowo taniej ochrony ubezpieczeniowej. Główną różnicą miedzy towarzystwem ubezpieczeń wzajemnych, a towarzystwem ubezpieczeń działającym jako spółka akcyjna jest to, że posiadają one klientów w bardzo ograniczonym zakresie. W momencie zawarcia umowy ubezpieczeniowej, ubezpieczający staje się zazwyczaj członkiem tuw-u i dzięki opłacaniu składek, ma prawo do udziału w walnych zgromadzeniach, wyboru władz i kontroli zarządu. Członkowie decydują również o tym, na co przeznaczona zostanie nadwyżka wynikająca $\mathrm{z}$ różnicy między zebraną składką a wypłaconym odszkodowaniem. W zależności od decyzji środki finansowe wracają do ubezpieczających, przyjmując postać zwrotu składki, obniżenia kosztów ubezpieczenia, podwyższenia sumy ubezpieczenia. Przyjęło się, że towarzystwa ubezpieczeń wzajemnych ubezpieczają niektóre grupy społeczne i zawodowe m.in. rolników, gminy i kościoły. W przypadku ubezpieczeń kościołów, sum ubezpieczenia i warunki umowy ustalane są na spotkaniu towarzystwa z dyrektorami ekonomicznymi kurii diecezjalnych. Spotkania te mają na celu zmianę świadomości ubezpieczeniowej opierającej się, w kościele, na błędnym myśleniu, że ubezpieczenie jest uciążliwą płatnością, a nie powinnością mającą zabezpieczyć wybudowany kościół. Niestety często obiekty sakralne ubezpieczone są na zbyt niskie sumy ubezpieczenia. Powoduje to, że w przypadku szkody całkowitej wypłacone odszkodowanie nie pokryłoby w pełni kosztów odbudowy kościoła. Ustalona suma ubezpieczenia jest niewystarczająca. Spowodowane jest to brakiem wystarczających dochodów na pokrycie wysokich składek

\footnotetext{
${ }^{11}$ Ustawa z dnia 22 maja 2003 r. o działalności ubezpieczeniowej (Dz. U. 2003 Nr 124 poz. 1151) - Obecnie obowiązuje : Ustawa z dnia 11 września 2015 r. o działalności ubezpieczeniowej i reasekuracyjnej Dz. U. Rzeczpospolitej Polskiej, poz.1844
} 
ubezpieczeniowych. Dlatego w przypadku wielu szkód, do odbudowy muszą dokładać się wierni. Wypłacane odszkodowanie stanowi jedynie podstawę do szybszego rozpoczęcia odbudowy. W przypadku diecezji ubezpieczonych w Towarzystwie Ubezpieczeń Wzajemnych kierują się one zasadą wewnętrznego solidaryzmu. Parafie wpłacają wcześniej ustaloną przez kurię sumę, która w całości trafia do towarzystwa na rzecz ubezpieczenia. O jej wysokości decyduje zazwyczaj kubatura kościoła. Wiąże się to $\mathrm{z}$ tym, że ewentualna wycena zabytkowego kościoła byłaby znacznie wyższa niż składka ubezpieczeniowa. Powszechnie stosowaną metoda jest ubezpieczenie diecezji jako całości, wówczas przedmiotem ubezpieczenia są parafie, diecezjalne seminarium, dom biskupi. Często zdarza się, że mienie znajdujące się $w$ kościołach nie jest ubezpieczane od kradzieży. Główną przyczyną jest brak zabezpieczeń antywłamaniowych, gdyż proboszczów po prostu nie stać na zakup profesjonalnego sprzętu. W przypadku takich obiektów firmy ubezpieczeniowe nie chcą ryzykować i odmawiają ubezpieczenia. Kościoły i mienie ruchome jest więc ubezpieczone jedynie od ognia i innych zdarzeń losowych, wyłączając kradzież.

Przykładem omawianej powyżej sytuacji jest ta, która dotyczy przypadku Katedry w Gorzowie Wielkopolskim. Umowa obejmowała budynki wraz z mieniem sakralnym od ognia i innych zdarzeń losowych. Ubezpieczenie zawarte było na zbyt niską kwotę w porównaniu z właściwą wartością. Spowodowało to wypłatę odszkodowania, które nie pokryje w pełni remontu wieży i przywrócenia jej do stanu sprzed pożaru. Z ustaleń biegłych pożarnictwa wynika, że przyczyną pożaru było zwarcie $w$ instalacji elektrycznej, powyżej poziomu dzwonów wieży katedralnej. Zniszczeniu uległa drewniana konstrukcja wieży z XVII w. Na szczęście udało się uratować dwie trzecie wieży. Straty powiększyły się podczas akcji gaśniczej, gdyż woda zalała wszystkie kondygnacje wieży i katedry, w tym emporę organową. Dodatkowo, zniszczeniu uległy tarcza zegara i blacha na kopule. Szacowany koszt remontu wnętrza i wieży zegarowej, ze względu na konieczność wykonania go „pod okiem” konserwatora zabytków może wynieść nawet $\mathbf{2 4} \mathbf{m l n}$. zl. Jest to kwota znacznie przewyższająca wypłacone odszkodowanie. Towarzystwo Ubezpieczeń Wzajemnych TUW po wnikliwym procesie likwidacyjnym wyplacilo odszkodowanie w wysokości $3 \mathrm{mln}$. zl. Pierwsza wypłata nastąiła praktycznie miesiąc po pożarze i wyniosła $1 \mathrm{mln}$. zł. Była to tzw. kwota bezsporna. Nawet pomimo wypłaty pieniędzy z budżetu państwa, odbudowa Katedry wspierana musi być przez parafian, prywatnych darczyńców, górników i przedsiębiorców.

Przykładem innej szkody precedensowej, jest pożar mostu Łazienkowskiego. Analizując tę szkodę trzeba zwrócić uwagę na specyfikę ubezpieczeń przez jednostki samorządu terytorialnego. Każda posiadająca osobowość prawną jednostka samorządu terytorialnego posiada majątek, którym dysponuje i zarządza. Czerpane z niego dochody służą do wykonywania przypisanych jej obowiązkowych zadań publicznych. Do majątku jednostek samorządu terytorialnego należą grunty, budynki, obiekty, sprzęt elektroniczny infrastruktura, floty pojazdów, maszyny i urządzenia, podmioty gospodarcze m.in. przedsiębiorstwa komunalne. Mienie to może być zróżnicowane, a niektóre jego składniki mogą mieć kompletnie inne znaczenie dla poszczególnych jednostek. Wymienione elementy majątku narażone są na ryzyko dlatego też, identyfikacja i ocena ryzyk musi zawierać wszystkie realizowane przez jednostkę 
samorządu terytorialnego i podmioty jej podlegające, cele i zadania. Do ryzyk z którymi mierzą się jednostki samorządu terytorialnego należą:

- skutki różnych zdarzeń losowych w mieniu,

- skutki kradzieży z włamaniem, rabunku i aktów wandalizmu,

- odpowiedzialność cywilna z tytułu prowadzonej działalności,

- skutki różnych zdarzeń losowych powodujących utratę zdrowia lub życia pracowników.

Jednostki samorządu terytorialnego najczęściej ubezpieczają swoją mienie od ognia $\mathrm{i}$ innych zdarzeń losowych, kradzieży z włamaniem, wandalizmu. Wybierają również ubezpieczenie szyb od stłuczenia i sprzętu elektronicznego oraz komunikacyjne flot pojazdów (ubezpieczenia OC, AC, NNW oraz assistance). Jednak największym powodzeniem cieszą się ubezpieczenia odpowiedzialności cywilnej za szkody na osobie lub mieniu z odpowiedzialnością wobec osób trzecich. Zgodnie z ustawą z dnia 29 stycznia 2004 r. Prawo Zamówień Publicznych ${ }^{12}$, zawarcie ubezpieczenia podlega postępowaniu w sprawie udzielania zamówienia publicznego. Szczegółowo opisywany jest przedmiot zamówienia, zakres ubezpieczenia, program ubezpieczenia oraz ustalenia sumy ubezpieczenia. Wystandaryzowany program ubezpieczeniowy, zostaje ogłoszony do publicznej wiadomości jako Specyfikacja Istotnych Warunków Zamówienia. Biorąc udział $\mathrm{w}$ przetargu, towarzystwa ubezpieczeniowe również muszą spełnić omawiane warunki. Dodatkowo upublicznione są kryteria doboru i oceny oferty. Powinny w głównej mierze uwzględniać jakość i zakres ochrony ubezpieczeniowej. Jednakże dość często głównym kryterium wyboru jest cena, a dokładniej wysokość składki. Jednostki samorządu terytorialnego bardzo często uzupełniają polisę o klauzule dodatkowe rozszerzające zakres ochrony. Przykładowo mogą dotyczyć:

- przewłaszczenia mienia - zachowanie ochrony ubezpieczeniowej pomimo przeniesienia własności ubezpieczonego mienia miedzy jednostkami organizacyjnymi, zmianą lokalizacji lub przeniesienia własności na nowo powołaną jednostkę samorządu terytorialnego.

- przepięcia - rozszerzenie ochrony ubezpieczeniowej o szkodę powstałą bezpośrednio lub pośrednio $\mathrm{w}$ wyniku wyładowania atmosferycznego, zmiany natężenia, częstotliwości i przepięcia.

- automatycznego pokrycia - objęcie ochroną nowo nabytych środków trwałych, wyposażenia oraz tych środków trwałych i ich wyposażenia, których wartość wzrosła w okresie ubezpieczenia, dzięki modernizacji lub remontom.

Bardzo ważne jest dokładne ocenienie stanu, wielkości i wartości posiadanego przez jednostkę samorządu terytorialnego mienia. Chroni to jednostkę samorządu terytorialnego od niedoubezpieczenia. Szczególnie jeżeli towarzystwo zastrzega użycie zasady proporcji w przypadku wystąpienia szkody przy niedoubezpieczeniu. Odszkodowanie wówczas wypłacone zostałoby proporcjonalnie do stosunku sumy ubezpieczenia do faktycznej wartości mienia. Trzeba jednak zauważyć, że procedura zamówienia publicznego, realizowana przez jednostki samorządu terytorialnego pozwala przynajmniej na swobodne ustalenie warunków i zakresu ubezpieczenia. Warunkiem jest jednak ustalenie takiej sumy ubezpieczenia aby gwarantowała pełne pokrycie szkody.

${ }^{12}$ Ustawa z dnia 29 stycznia 2004 r. Prawo Zamówień Publicznych (Dz.U. 2004 Nr 19 poz. 177) 
Do pożaru mostu Łazienkowskiego doszło 14 lutego 2015 r. Rozpoczął się niegroźnie, bo od niewielkiego pożaru desek, znajdujących się w składzie pod nim po praskiej stronie Wisły. Niestety ogień szybko się rozprzestrzenił i objął drewniany podest pomostu technicznego i rozprzestrzeniał się dalej. Bardzo wysoka temperatura spowodowała dodatkowo zniszczenia i odkształcenia nawierzchni przeprawy. Z ekspertyzy wynikało, iż ze względu na duże szkody, niezbędna była wymiana całej konstrukcji mostu, za wyjątkiem filarów. Prace remontowe prowadzone przez konsorcjum PORR Polska Infrastructure i Przedsiębiorstwo Usług Technicznych „Intercor” przez 6 miesięcy spowodowały spore utrudnienia komunikacyjne w Warszawie. Koszt odbudowy obiektu wyniósł ponad $100 \mathrm{mln}$ zl, z czego połowa została przekazana przez rząd.

Program ubezpieczenia majątku i działalności cywilnej m.st. Warszawy rozpoczął się w 2011 roku. Stworzenie tego programu miało na celu ujednolicenie sposobu zabezpieczania majątku i odpowiedzialności cywilnej jednostek samorządu terytorialnego, które miały odmienne podejście do ubezpieczenia. Jedne z nich nie ubezpieczały się wcale, inne kompleksowo, a jeszcze inne chroniły tylko część majątku lub odpowiedzialność cywilną. Ponadto wiele zawieranych umów było niedopasowanych pod kątem wysokości sumy ubezpieczenia i limitów do specyfiki działalności jednostki. Przetarg mający wyłonić ubezieczycieli na lata 2014-2015 dotyczył trzech rodzajów ubezpieczeń:

- Ubezpieczenia OC związanego z działalnością prowadzoną przez miasto i z majątkiem miejskim,

- Ubezpieczenie majątku,

- Ubezpieczenie komunikacyjne.

Zadeklarowane do ubezpieczenia mienie obejmowało budynki i budowle (w szczególności: drogi, mosty, wiadukty), przejścia podziemne, tunele, kładki, chodniki, płoty, bariery energochłonne, ekrany akustyczne, bramy, balustrady, infrastrukturę kanalizacji deszczowej i sanitarnej, torowisko Węzła Komunikacyjnego Młociny, szalety miejskie, wiaty i słupki przystankowe, fontanny i inne obiekty małej architektury, pomniki, rzeźby i kompozycje przestrzenne, punkty informacyjne, pionowe oznakowanie dróg, zadaszenia basenów, zadaszenia kortów tenisowych, zadaszenia lodowisk, boiska sportowe, studnie oligoceńskie, sygnalizację świetlną wraz z infrastrukturą towarzysząca, słupy oświetleniowe i wiele innych. Dotyczyło to również mienia, które nie było użytkowane przez miasto lub zostało przekazane przez osoby trzecie. Zgodnie z Specyfikacją Istotnych Warunków Zamówienia, o wyborze oferty ubezpieczyciela decydowała największa liczba zdobytych punktów. Za klauzule dodatkowe, ubezpieczyciel otrzymywał 20\% punktów, natomiast za najlepszą cenę brutto, aż 80\%. Elementy umowy, w tym zakres, wysokość sum ubezpieczenia, zbiór klauzul były jednakowo ustalane przez Ratusz dla wszystkich oferentów. Ubezpieczenia mienia podjęło się Towarzystwo Ubezpieczeniowe Uniqa. Wartość ubezpieczonych składników mienia wynosiła 10 mld zł. Niestety nie wszystkie zabezpieczone elementy mienia ubezpieczone były na sumy odpowiadające ich wartości. Podniesienie sumy ubezpieczenia zwiększało bowiem wysokość składki. Dlatego też, wiele jednostek organizacyjnych ubezpieczonych było w ramach klauzul. Jedna $\mathrm{z}$ nich dotyczyła infrastruktury drogowo-mostowej podlegającej ubezpieczenia od wszystkich ryzyk, 
zawierająca limit wypłat na kwotę 3 mln. zł dla konkretnego zdarzenia. Umowa zawierała jeszcze inne ograniczenia. Należały do nich:

- limit wypłat odszkodowań za dany rok,

- limit wypłat w przypadku majątku niewskazanego do ubezpieczenia w pełnej wartości,

- limit uzyskania odszkodowania w przypadku złego oszacowania wartości jakiegoś składnika mienia,

- wyłączenie z ubezpieczenia infrastrukturę, w tym drogi i tunele wybudowane przez $1990 \mathrm{r}$.

- limit wypłaty odszkodowań związanych z zamieszkami i dewastacjami w wyniku zdarzeń o charakterze społecznym - wynosił $5 \mathrm{mln}$ zł,

- limit na szkody związane z powodzią - 200 mln zł.

W wyniku zaistniałych zapisów w umowie ubezpieczenia, maksymalne odszkodowanie za pożar mostu Lazienkowskiego wyniosło $3 \mathrm{mln}$. zl. Decyzja o takim limicie podjęta została na podstawie statystycznych wyliczeń wysokości wypłat z ubezpieczenia na pokrycie szkód w infrastrukturze drogowo-mostowej. Więcej szkód $\mathrm{w}$ tej infrastrukturze pokrywanych było z ubezpieczenia od odpowiedzialności cywilnej sprawcy. Jest to ewidentny przykład nieprawidłowego oszacowania ryzyka oraz determinowania sumy ubezpieczenia wysokością składki. Gdyby klauzula dotycząca infrastruktury drogowo-mostowej była zniesiona, m.st. Warszawa musiałoby wówczas zapłacić składkę w wysokości około $50 \mathrm{mln}$. zł rocznie, a nie $12,5 \mathrm{mln}$ zł. Wybór wysokości tego limitu argumentowano tym, że jest kwota najwyższa w Polsce, w przypadku tego przedmiotu ubezpieczenia. Wiele mostów w Polsce w ogóle nie jest ubezpieczonych. Dotyczy to jedynie nowych konstrukcji, które i tak ubezpieczane są na niższe kwoty. Ich wysokość przedstawia Tabela 2.

Tabela 2. Wysokość limitów odszkodowań w innych miastach Polski

\begin{tabular}{ll}
\hline Miasto & Limit odszkodowania \\
\hline Toruń & 500 tys. zł \\
\hline Rzeszów & $1 \mathrm{mln} \mathrm{zł}$ \\
\hline Zielona Góra & $1 \mathrm{mln} \mathrm{zł}$ \\
\hline Gdańsk & $2 \mathrm{mln} \mathrm{zł}$ \\
\hline
\end{tabular}

Źródło: Opracowanie własne na podstawie protokołu VIII/5 obrad VIII sesji Rady m.st. Warszawy z dnia 26.03.2015 r.

Omówione powyżej zdarzenie nie spowodowało znaczących zmian w polityce ubezpieczeniowej m.st. Warszawy. Proporcje zastosowane w ocenie ofert zostały nieznacznie zmienione $-70 \%$ cena, 30\% zakres ubezpieczenia. Głównym wyznacznikiem wyboru oferty nadal jest wysokość składki, czyli cena ubezpieczenia.

\section{Wnioski}

Nieprawidłowo dobrana suma ubezpieczenia przyczynia się do zmniejszenia wypłacanego odszkodowania za powstałą szkodę. Niedoubezpieczenie charakteryzuje się zbyt niską sumą ubezpieczenia w stosunku do wartości przedmiotu ubezpieczenia. Największy problem dla klientów taka sytuacja stanowi w przypadku szkód całkowitych. Wypłata odszkodowania, zgodnie z OWU ograniczona jest zawsze sumą 
ubezpieczenia. W przypadku niedoubezpieczenia ubezpieczony musi samodzielnie dofinansować naprawę, gdyż wypłacone odszkodowanie jest niewystarczające na pokrycie szkody. Powodem zaniżania sumy ubezpieczenia jest chęć obniżenia wysokości płaconej składki. Dodatkowo problemem w przypadku niedoubezpieczenia są niektóre zapisy w umowach ubezpieczenia. Szczególnie zapis wprowadzający zasadę proporcji przy ustalaniu wysokości odszkodowania. W przypadku stwierdzenia niedoubezpieczenia przekraczającego np. 30\%, wartość odszkodowania pomniejszona zostanie w takim stopniu, w jakim suma ubezpieczenia przedmiotu ubezpieczenia jest zaniżona w stosunku do faktycznej jego wartości w dniu zaistnienia szkody.

Tania polisa ubezpieczeniowa często nie jest najlepszą opcją ubezpieczenia dla klienta, gdyż nie jest w stanie zapewnić naprawienia zaistniałej szkody. Dlatego też dokładne ustalenie sumy ubezpieczenia jest bardzo ważne. Dodatkowo przy zawieraniu umowy ubezpieczenia trzeba zwrócić uwagę na inne jej warunku np. dotyczące rodzaju sum ubezpieczenia, wyłączeń czy franszyzy.

W przypadku zakupu ochrony ubezpieczeniowej bardzo ważna jest znajomość poprawnego sposoby szacowania wartości mienia. Klienci często szacują wartość mienia „na oko”. Wartość mienia, powinna być szacowana na podstawie wartości odtworzeniowej, wartości rynkowej, wartości rzeczywistej, wartości księgowej brutto lub wartości księgowej netto.

W ubezpieczeniu mienia, wartość majątku najczęściej określana jest na podstawie wartości odtworzeniowej, wartości rzeczywistej lub wartości księgowej brutto. Wybór właściwego sposobu określania wartości mienia jest bardzo istotny, gdyż to on określa wysokość przyznanego odszkodowania. Ubezpieczenie na wartość księgowa brutto jest najszybszym i niewątpliwie najłatwiejszym sposobem ustalania wartości mienia. Sposób ten sprawdza się jedynie dla nowego majątku. Im dawniej zakupiony majątek, tym większa różnica między wartością początkową i rzeczywistą. Otrzymane odszkodowanie nie pokryje wówczas odbudowy majątku. Najbardziej racjonalnym sposobem jest określanie wysokości mienia na podstawie wartości odtworzeniowej. Daje on możliwość odtworzenia mienia w całości. Jest to jednak sposób znacznie droższy niż ubezpieczenie na wartość rzeczywistą bądź wartość księgową brutto. Należy jednak pamiętać o aktualizacji sumy ubezpieczenia. Każde powiększenie majątku powinno skutkować zwiększeniem wysokości sumy ubezpieczenia.

Problem ten dotyczy nie tylko klientów indywidualnych ale również obiektów sakralnych i jednostek samorządu terytorialnego. Gdyby parafie przeznaczały większe kwoty na ubezpieczenie, diecezje mogłyby ubezpieczyć mienie na znacznie wyższe kwoty, a wypłacane odszkodowanie pokryłoby koszty napraw. Niestety parafii nie stać na wyższe stawki ubezpieczeniowe. Proboszcz przeznacza maksymalną kwotę jaką może przeznaczyć na ubezpieczenie swojej parafii. W konsekwencji nie są usatysfakcjonowani z wysokości odszkodowania, jednak mają świadomość, że jest to jedyna możliwa wielkość jaką mogą otrzymać na podstawie takich warunków i zakresu ubezpieczenia.

Zadziwiające jest, że jednostki samorządu terytorialnego, posiadające większe zasoby pieniężne również determinują wybór oferty ubezpieczeniowej wysokością składki. Dodatkowo szacowanie ryzyka na podstawie wysokości wcześniejszych wypłat odszkodowań też nie jest metodą zadowalająca. Być może gdyby zastosowano inną metodę szacowania ryzyka, uwzględniającą możliwość wystąpienia jednej najwyższej 
szkody, skutki pożaru mostu Łazienkowskiego nie byłyby tak dotkliwe. Składka ubezpieczeniowa byłaby wyższa ale szkoda zostałaby pokryta w całości.

Przedstawione w opracowaniu przykłady w formie studium przypadku dowodza, że próba oszczędzania na składce powoduje, iż w sytuacji realizacji zdarzenia ubezpieczający musi częściowo pokryć naprawę zniszczonego mienia. Ubezpieczający decydując się na ustalenie niższej sumy ubezpieczenia musi liczyć się z wypłatą odszkodowania nierekompensującego szkodę. Występujące w takiej sytuacji niedoubezpieczenie, jest przyczyną niezadowalającego klientów zakończenia procesu zarządzania ryzkiem poprzez ubezpieczenie. To właśnie skargi dotyczące wypłaty odszkodowania są jednymi z najczęściej trafiających do Rzecznika Finansowego. W praktyce jednak ostateczna decyzja odnośnie wysokości sumy ubezpieczenia należy do klienta, który mimo przedstawienia mu wszystkich aspektów niewłaściwego jej określenia i tak decyduje się na zaniżenie wartości ubezpieczonego mienia, ze względu na wysokość składki ubezpieczeniowej.

Dużym krokiem poczynionym $\mathrm{w}$ kierunku naprawy sytuacji wynikających $\mathrm{z}$ przyjęcia przez strony umowy ubezpieczeniowej złej wartości ubezpieczenia jest rozstrzyganie przez Sąd Najwyższy na korzyść ubezpieczającego, spraw dotyczących niedoubezpieczenia. Zdaniem Sądu Najwyższego to ubezpieczyciel powinien dopilnować aby suma ubezpieczenia odpowiadała wartości ubezpieczonego mienia. Ubezpieczający nie jest specjalistą w dziedzinie ubezpieczeń, dlatego nie powinno się obciążać go dodatkowym zaniżeniem odszkodowania. Skoro składka ubezpieczeniowa odpowiada ryzyku ubezpieczyciela i jest pobierana od kwoty ubezpieczenia, wówczas wysokość odszkodowania powinna być ustalana od sumy ubezpieczenia, a nie od wartości mienia. Dlatego też, wiele towarzystw ubezpieczeniowych postanowiło znieść zasadę proporcji.

Dobrze dobrane do potrzeb ubezpieczającego ubezpieczenie na etapie ustalania warunków umowy, to punkt wyjścia, który determinuje wszystko to, co zdarzy się później w procesie likwidacji szkody. Oznacza, to że likwidacja szkody zaczyna się na etapie zakupu ubezpieczenia. Decyzje podejmowane przez ubezpieczyciela w trakcie likwidacji szkody są ściśle uzależnione od treści umowy ubezpieczenia. Jej właściwy zakres powoduje, że w przypadku szkody wysokość odszkodowania jest satysfakcjonująca dla poszkodowanego, a sama likwidacja szkody może zostać przeprowadzona sprawnie i w znaczący sposób pomóc klientowi. Dobrze dobrane ubezpieczenie ułatwia sprawną likwidację nawet przy skomplikowanej szkodzie o dużej wartości.

\section{Bibliografia}

Hadyniak B., Monkiewicz J., Ubezpieczenia w zarządzaniu ryzykiem przedsiębiorstwa tom 1, Warszawa 2010

Kaczmarek M., Ubezpieczenia majatkowe dla podmiotów gospodarczych [w]: E. Wierzbicka,

Ubezpieczenia non-life, CeDeWu Sp. z o.oWarszawa 2010

Orlicki M., Umowa ubezpieczenia, C.H. Beck, Warszawa 2002

Protokół VIII/5 obrad VIII sesji Rady m.st. Warszawy z dnia 26.03.2015 r.

Ronka-Chmielowiec W., Ubezpieczenia, C.H. Beck, Warszawa 2016 
Stempel R., Ubezpieczenia inżynieryjno-techniczne, wyd.UWM Olsztyn, Olsztyn 2013 http://www.uwm.edu.pl/pro-

edu/upload/file/podreczniki/Zad.2/Ubezpieczenia\%20inzynieryjno\%20-\%20techniczne.pdf

Strupczewski G., Ryzyko i zarządzanie ryzykiem [w:] Współczesne ubezpieczenia gospodarcze, pod red. W. Sułkowskiej, Wydawnictwo Uniwersytetu Ekonomicznego w Krakowie, Kraków 2013

Szromnik A., Rynek ubezpieczeniowy. Społeczne problemy kształtowania i funkcjonowania, Akademia Ekonomiczna w Krakowie, Kraków 2001

Ustawa z dnia 11 września 2015 r. o działalności ubezpieczeniowej i reasekuracyjnej Dz. U. Rzeczpospolitej Polskiej, poz.1844

Ustawa z dnia 22 maja 2003 r. o działalności ubezpieczeniowej (Dz. U. 2003 Nr 124 poz. 1151)

Ustawa z dnia 22 maja 2003 r. o ubezpieczeniach obowiązkowych, Ubezpieczeniowym Funduszu Gwarancyjnym i Polskim Biurze Ubezpieczycieli Komunikacyjnych (t.j. Dz.U.2018.0.473)

Ustawa z dnia 23 kwietnia 1964 - Kodeks cywilny (t.j. Dz. U. z 2014 r., poz. 121) art. 824 ust. 1 Ustawa z dnia 29 stycznia 2004 r. Prawo Zamówień Publicznych (Dz.U. 2004 Nr 19 poz. 177)

Wicka A. Finanse ubezpieczeń gospodarczych [w:] Finanse-teoria i praktyka. Podstawka M. (red.) PWN, Warszawa 2017

Williams A.C. J r., Smith M.L., Young P.C., Zarządzanie ryzykiem a ubezpieczenia, PWN, Warszawa 2002

\section{Summary}

The importance of the method of determining the sum insured in process of risk management through insurance The purpose of this thesis is to present the consequences of determining the sum insured based on the improper value of the subject of insurance. The conclusion is based on the analysis underwriting contracts for a church and a local government unit. The study presents the problem of underinsurance based on the source literature and loss documentation. The results of the analysis confirm the thesis that underinsurance is the cause of incorrect and unsatisfactory completion of the risk management process through insurance.

Key words: insurances, sum insured, value of the subject of insurance, underwriting contract, risk management, insurance indemnity

Informacja o Autorach:

Paulina Matracka

Dr inż. Aleksandra Wicka

Katedra Polityki Europejskiej i Marketingu

WNE SGGW w Warszawie

Ul. Nowoursynowska 166

02-787 Warszawa

e-mail: aleksandra wicka@sggw.pl.

ORCID: 0000-0001-7713-4953 